\title{
Quality of Life in an Adult Population of More than 60 Years of Age without Cognitive Impairment
}

\author{
Miren Zuriñe García Villanueva Juan María Uterga Valiente \\ Alfredo Rodríguez-Antigüedad Zarranz
}

Neurology Department, Hospital Universitario de Basurto, Bilbao, Spain

Key Words

Quality of life · SF-36 · Elderly population · Not institutionalised - Leisure activities .

Without cognitive impairment

\section{Abstract}

Objectives: To analyse the quality of life (QoL) of persons over 60 years of age in Bizkaia (Basque Country, Spain), not institutionalised and without cognitive impairment, and the relation and possible influence of the perception of the state of health with the cognitive level and the activities that they carry out. Subjects and Methods: Evaluation of a sample of 317 persons that belong to a longitudinal study. In 269 cases, there was a reliable informant. The general cognitive state was evaluated by means of the Mini-Mental State Examination (MMSE) and the Global Deterioration Scale (GDS). Two GDS, one of the family member (GDSf) and another of the evaluator (GDSe), were used and memory was evaluated by the Text Memory subtest of the Barcelona Test. The QoL was assessed with the SF-36 Health Survey and the mental, physical and social activities that they carry out were recorded. Results: In the SF-36, the participants showed values that exceed the reference values of the Spanish population in all dimensions of the SF-36, except in that of bodily pain. There were low correlations between the dimensions of the SF-36 and the mental, physical and social activities. A low correlation was observed between the memory tests and the SF-36. In 59.3\% of the cases, there were no differences between the GDSf and the GDSe. Conclusions: The participants of this study present a better perception of their state of health than the Spanish population, but this perception is not observed to be influenced by the type or by the quantity of activities that they carry out or by their cognitive state. The informants present a vision very close to the cognitive state of their family members. 


\section{Introduction}

Ageing entails an increase in chronic illnesses and in disabled persons [1]. In our region, there are many persons who reach advanced ages, but it is not known exactly with what quality of life (QoL) they do so. QoL, according to the World Health Organisation, is the perception that an individual has of his place of existence, in the context of culture and of the system of values in which he lives in relation to his expectations, his rules and his concerns, and it is influenced in a complex way by the physical health of the subject, his psychological state, his level of independence, his social relations, as well as by his relation with the essential elements of his environment.

Many studies have been conducted on the QoL of persons with different illnesses [2, 3], few studies on older adults [4], and very few on independent older adults [5]. For this reason, the objective of this study is to describe and analyse the characteristics of a group of persons over 60 years of age living in Bizkaia (Basque Country, Spain), not institutionalised, independent and without cognitive impairment, and to establish an association between the QoL, the cognitive state and performing leisure activities.

\section{Subjects and Methods}

\section{Collection of Data}

This is a longitudinal study directed by the Hospital Universitario de Basurto (Basque Country, Spain) that began in 2007 and that currently continues in centres for retired persons of Bizkaia belonging to the Bilbao Bizkaia Kutxa (Kutxabank) or in those of the Associations of Retired Persons of Bilbao.

The persons comprising our sample were elderly, had no cognitive impairment, participated voluntarily and lived independently in their homes. The inclusion criteria were: being over 60 years of age, not having suffered a stroke, not suffering any psychiatric or neurological illness and not having suffered a sensory problem or any other that makes impossible the administering of the tests, being independent, leading an autonomous lifestyle and wanting to participate voluntarily by means of signing an informed consent form. They presented a score on the Mini-Mental State Examination (MMSE) over the 25th percentile [6].

\section{Subjects}

The analysed sample was comprised of 317 persons: 81 men (25.6\%) and 236 women (74.4\%), over 60 years of age, with a mean age of 74.16 years and a mean of 7.8 years of schooling. The majority either lived with their spouse or alone (with spouse $46.4 \%$, alone $30.3 \%$; table 1). Of these 317 persons, there was a reliable informant in 269 of the cases. The persons that comprise our sample presented a mean score of 27.45 on the MMSE.

\section{Instruments}

Risk factors of cognitive deterioration [7-13] were collected, such as arterial hypertension, hypercholesterolaemia, diabetes mellitus, currently being a smoker or having been a smoker, heart disease, and family history of cognitive deterioration or dementia. The cognitive level was evaluated using the MMSE [14] and the Text Memory subtest of the Revised Barcelona Test [15], and the QoL was assessed by means of the Spanish version 1.4 of the SF-36 Health Survey [16], the activities carried out in their free time or leisure activities (LA) [17] divided into social, physical and intellectual activities, and the Global Deterioration Scale (GDS) [18]. The GDS score was obtained from a reliable informant referred to as the GDS of the family member (GDSf) scored according to the information provided by the latter, and 
Table 1. Descriptive data of the sample

\begin{tabular}{l|l}
\hline \multicolumn{2}{l}{ Dement Geriatr Cogn Disord Extra 2014;4:355-363 } \\
\hline DOI: 10.1159/000365505 & $\begin{array}{l}\text { ○ 2014 S. Karger AG, Basel } \\
\text { www.karger.com/dee }\end{array}$ \\
\hline $\begin{array}{l}\text { Garcia Villanueva et al.: Quality of Life in an Adult Population of More than 60 Years of } \\
\text { Age without Cognitive Impairment }\end{array}$ \\
\hline \\
\hline Gender \\
Male \\
Female \\
Total & $81(25.6 \%)$ \\
\hline Inhabitation & $236(74.4 \%)$ \\
Couple, marriage & 317 \\
Alone & $147(46.4 \%)$ \\
Spouse and children & $96(30.3 \%)$ \\
With son/daughter & $31(9.8 \%)$ \\
Son/daughter and grandchildren & $28(8.8 \%)$ \\
Others & $3(0.9)$ \\
Total & $12(3.8 \%)$ \\
\hline
\end{tabular}

from the GDS of the evaluator (GDSe) scored by taking into account information from the subject, from the informant and the score on the Deferred Memory Texts of the Barcelona Test and GDSf. The reliable informant is a family member with whom regular contact is maintained reporting on the state of the study participant by telephone; importantly, the informant does not present any psychiatric or neurological problem that disables him/her as an informant. As for the SF-36 survey, it is comprised of 36 items that evaluate the following dimensions or scales of the health-related QoL: physical functioning, role-physical, bodily pain, general health, vitality, social functioning, role-emotional and mental health. In addition, two sums, the physical health component and the mental health component, were considered. The items generate a scale for each dimension that goes from 0 to 100 and is administered by means of an interview $[19,20]$. Blood was also extracted to form part of the Genetic Bank of the Hospital Universitario de Basurto, after having signed an informed consent form.

\section{Statistical Analysis}

The statistical analysis was conducted with the SPSS v. 15.0 program for Windows. Descriptive analyses of all the sociodemographic variables, risk factors and other information collected on the persons included in our sample, as well as the frequencies, percentages, means and standard deviations were included.

Data were collected of the eight areas of the SF-36, for the total sample as well as divided by gender. The dimensions and sums of the SF-36 were correlated with the activities carried out in their free time.

The difference between the two GDS (GDSd) was calculated in order to find the level of awareness of the family member with respect to the cognitive state of the subject and correlations of the GDSd with the memory tests. The correlations of the memory tests, MMSE and Immediate Texts and Deferred Texts of the Barcelona Test were also calculated with the dimensions of the SF-36 and with the different activities that are performed by the participants.

\section{Results}

Among the risk factors of cognitive deterioration, the presence of arterial hypertension stands out in $53.3 \%$, while $38.5 \%$ presented hypercholesterolaemia, $14.5 \%$ diabetes mellitus, $4.1 \%$ had been smokers and $22.4 \%$ were suffers or had suffered a heart disease. As for the number of activities that they carry out in their free time (table 2), the activities that most perform are the physical and intellectual activities (45.1\% carry out a physical activity and $37.2 \%$ an intellectual activity). 
Table 2. Number and percentage of individuals carrying out different activities in their free time

Table 3. Mean scores \pm SD of the dimensions of the SF-36 Health Survey

\begin{tabular}{l|l}
\hline Dement Geriatr Cogn Disord Extra 2014;4:355-363 \\
\hline DOI: $10.1159 / 000365505$ & $\begin{array}{l}\text { ( 2) 2014 S. Karger AG, Basel } \\
\text { www.karger.com/dee }\end{array}$ \\
\hline
\end{tabular}

Garcia Villanueva et al.: Quality of Life in an Adult Population of More than 60 Years of Age without Cognitive Impairment

\begin{tabular}{lccr}
\hline $\begin{array}{l}\text { Number of } \\
\text { activities }\end{array}$ & $\begin{array}{l}\text { Social } \\
\text { activities }\end{array}$ & $\begin{array}{l}\text { Physical } \\
\text { activities }\end{array}$ & $\begin{array}{l}\text { Intellectual } \\
\text { activities }\end{array}$ \\
\hline 0 & $292(92.1 \%)$ & $71(22.4 \%)$ & $65(20.5 \%)$ \\
1 & $19(6 \%)$ & $143(45.1 \%)$ & $118(37.2 \%)$ \\
2 & $5(1.6 \%)$ & $73(45.1 \%)$ & $82(25.9 \%)$ \\
3 & $1(0.3 \%)$ & $21(6.6 \%)$ & $36(11.4 \%)$ \\
4 & & $8(2.5 \%)$ & $10(3.2 \%)$ \\
5 & & $1(0.3 \%)$ & $4(1.3 \%)$ \\
6 & & & $2(0.6 \%)$ \\
\hline
\end{tabular}

\begin{tabular}{|c|c|c|}
\hline Dimensions of the SF-36 & $\begin{array}{l}\text { Mean score } \pm \\
\text { SD }\end{array}$ & $\begin{array}{l}\text { Reference } \\
\text { values }\end{array}$ \\
\hline \multicolumn{3}{|l|}{ Total } \\
\hline Physical functioning & $79.9 \pm 18.4$ & $65.7 \pm 29.8$ \\
\hline Role-physical & $75.3 \pm 37.8$ & $73.3 \pm 41.1$ \\
\hline Bodily pain & $64.0 \pm 29.8$ & $68.4 \pm 29.9$ \\
\hline General health & $65.9 \pm 20.1$ & $55.9 \pm 21.5$ \\
\hline Vitality & $66.7 \pm 20.9$ & $60.5 \pm 24.7$ \\
\hline Social functioning & $93.4 \pm 15.3$ & $79.2 \pm 28.0$ \\
\hline Role-emotional & $80.5 \pm 34.5$ & $84.8 \pm 32.9$ \\
\hline Mental health & $72.4 \pm 18.3$ & $68.3 \pm 22.3$ \\
\hline \multicolumn{3}{|l|}{ Women } \\
\hline Physical functioning & $77.1 \pm 19.2$ & $60.5 \pm 28.6$ \\
\hline Role-physical & $71.6 \pm 39.8$ & $68.5 \pm 40.4$ \\
\hline Bodily pain & $59.6 \pm 29.8$ & $62.8 \pm 28.9$ \\
\hline General health & $64.8 \pm 20.4$ & $53.2 \pm 20.0$ \\
\hline Vitality & $63.1 \pm 21.1$ & $55.9 \pm 23.3$ \\
\hline Social functioning & $92.2 \pm 16.9$ & $74.9 \pm 27.9$ \\
\hline Role-emotional & $75.9 \pm 37.1$ & $80.3 \pm 34.3$ \\
\hline Mental health & $69.1 \pm 18.2$ & $62.9 \pm 21.4$ \\
\hline \multicolumn{3}{|l|}{ Men } \\
\hline Physical functioning & $88.0 \pm 12.8$ & $72.5 \pm 30.2$ \\
\hline Role-physical & $86.1 \pm 29.0$ & $79.7 \pm 41.2$ \\
\hline Bodily pain & $77.0 \pm 26.0$ & $75.7 \pm 29.8$ \\
\hline General health & $69.1 \pm 19.0$ & $59.3 \pm 23.3$ \\
\hline Vitality & $77.2 \pm 16.3$ & $66.4 \pm 25.5$ \\
\hline Social functioning & $97.0 \pm 8.4$ & $84.8 \pm 26.9$ \\
\hline Role-emotional & $93.8 \pm 20.4$ & $90.7 \pm 29.2$ \\
\hline Mental health & $81.9 \pm 14.8$ & $75.3 \pm 21.6$ \\
\hline
\end{tabular}

Table 3 shows the results of the eight dimensions of the SF-36 compared to the reference values of the Spanish version of this test in a population over 60 years of age [21]. In all the dimensions, values above the reference values were presented except in the dimension of bodily pain. The dimensions with the greatest difference with respect to the reference values are physical functioning and social functioning. In the bodily pain dimension, a lower score was found, which would indicate that they suffer less pain. As for the gender-based data, the women presented better scores in all the dimensions except in the role-emotional and bodily pain dimensions, and in the case of the men, higher scores were presented in all the scales.

As for the LA, in the physical activities a mean of 1.23 was observed, in the intellectual activities, 1.46 and in social activities, 0.10 . The correlations of the eight dimensions of the 
Table 4. Correlations of the eight dimensions and the two sums of the SF-36 with the activities carried out in the free time

\begin{tabular}{|c|c|c|c|c|c|}
\hline & Pearson & $\begin{array}{l}\text { Physical } \\
\text { activities }\end{array}$ & $\begin{array}{l}\text { Intellectual } \\
\text { activities }\end{array}$ & $\begin{array}{l}\text { Social } \\
\text { activities }\end{array}$ & $\begin{array}{l}\text { Total number } \\
\text { of activities }\end{array}$ \\
\hline \multirow[t]{2}{*}{ PF } & correlation & $0.195^{* *}$ & -0.061 & 0.013 & 0.076 \\
\hline & sig. (bilateral) & 0.000 & 0.282 & 0.820 & 0.178 \\
\hline \multirow[t]{2}{*}{$\mathrm{RF}$} & correlation & $0.193^{* *}$ & 0.067 & -0.041 & $0.153^{* *}$ \\
\hline & sig. (bilateral) & 0.001 & 0.237 & 0.466 & 0.006 \\
\hline \multirow[t]{2}{*}{$\mathrm{BP}$} & correlation & $0.124^{*}$ & 0.032 & 0.056 & 0.109 \\
\hline & sig. (bilateral) & 0.028 & 0.571 & 0.319 & 0.052 \\
\hline \multirow[t]{2}{*}{$\mathrm{GH}$} & correlation & $0.165^{* *}$ & 0.064 & 0.034 & $0.151^{* *}$ \\
\hline & sig. (bilateral) & 0.003 & 0.254 & 0.550 & 0.007 \\
\hline \multirow[t]{2}{*}{ VT } & correlation & $0.189^{* *}$ & 0.020 & -0.023 & $0.121^{*}$ \\
\hline & sig. (bilateral) & 0.001 & 0.723 & 0.687 & 0.031 \\
\hline \multirow[t]{2}{*}{ SF } & correlation & 0.105 & $0.158^{* *}$ & 0.011 & $0.177^{* *}$ \\
\hline & sig. (bilateral) & 0.063 & 0.005 & 0.840 & 0.002 \\
\hline \multirow[t]{2}{*}{$\mathrm{RE}$} & correlation & 0.085 & $0.232^{* *}$ & -0.043 & $0.206^{* *}$ \\
\hline & sig. (bilateral) & 0.132 & 0.000 & 0.443 & 0.000 \\
\hline \multirow[t]{2}{*}{$\mathrm{MH}$} & correlation & 0.066 & $0.184^{* *}$ & 0.034 & $0.178^{* *}$ \\
\hline & sig. (bilateral) & 0.240 & 0.001 & 0.545 & 0.002 \\
\hline \multirow[t]{2}{*}{ PCS } & correlation & $0.214^{* *}$ & -0.071 & 0.023 & 0.082 \\
\hline & sig. (bilateral) & 0.000 & 0.204 & 0.685 & 0.146 \\
\hline \multirow[t]{2}{*}{ MCS } & correlation & 0.048 & $0.250^{* *}$ & -0.017 & $0.202^{* *}$ \\
\hline & sig. (bilateral) & 0.391 & 0.000 & 0.768 & 0.000 \\
\hline
\end{tabular}

$\mathrm{PF}$ = Physical functioning; $\mathrm{RP}$ = role-physical; $\mathrm{BP}$ = bodily pain; $\mathrm{GH}$ = general health; $\mathrm{VT}$ = vitality; $\mathrm{SF}=$ social functioning; $\mathrm{RE}=$ role-emotional; $\mathrm{MH}=$ mental health; $\mathrm{PCS}=$ physical component sum; $\mathrm{MCS}=$ mental component sum. ${ }^{*} \mathrm{p}=0.05$ (bilateral); ${ }^{* *} \mathrm{p}=0.01$ (bilateral). Number of participants: $\mathrm{n}=317$.

SF-36 and its two sums with the different LA as well as with their total score were significant but low in some cases (table 4).

Considering the difference between the GDSf and GDSe, the family members have a good perception of the study subjects since of the 269 persons with informants, $188(58.3 \%)$ presented a difference between the two GDS of 0 points; 76 cases showed 1 point (24\%) and only 5 cases 2 points $(1.6 \%)$ (table $5 a$ ). The correlations of the GDSd with the memory tests are significant but weak. The strongest is a negative correlation with the Deferred Texts $(-0.742)$ (table $5 b)$.

As for the neuropsychological tests, the MMSE and the Immediate and Deferred Texts of the Barcelona Test, and the correlations of these with the dimensions of the SF-36 and their sums are very weak (table 6). In the case of the MMSE, only three correlations are very significant: those with the dimension of role-emotional, mental health and the sum of the mental health component. The correlation of Immediate Text is only significant with the dimension of mental health and the correlation of Deferred Text is significant with vitality, mental health and with the sum of the mental health component.

\section{Discussion}

In this study, good scores in the SF-36 dimensions were expected as it dealt with persons without cognitive impairment and who were independent; the scores obtained for the mental health and functional capacity are considered the factors that most influence the perception 
Dementia

and Geriatric

Cognitive Disorders

Table 5. GDS score and the correlation with the memory tests \begin{tabular}{l|l}
\hline Dement Geriatr Cogn Disord Extra 2014;4:355-363 \\
\hline DOI: $10.1159 / 000365505$ & $\begin{array}{l}\text { C 2014 S. Karger AG, Basel } \\
\text { www.karger.com/dee }\end{array}$ \\
\hline Garcia Villanueva et al.: Quality of Life in an Adult Population of More than 60 Years of
\end{tabular} Garcia Villanueva et al.: Quality of Life
Age without Cognitive Impairment

a Score of the two GDS and the difference between them

\begin{tabular}{lrr}
\hline & Number & Percentage \\
\hline GDSe & & \\
1 & 195 & 61.5 \\
2 & 112 & 35.3 \\
3 & 10 & 3.2 \\
Total & 317 & \\
GDSf & & \\
1 & 239 & 75.4 \\
2 & 29 & 9.1 \\
3 & 1 & 0.3 \\
Total & 269 & \\
GDSd & & \\
0 & 188 & 59.3 \\
1 & 76 & 24.0 \\
2 & 5 & 1.6 \\
Total & 269 & \\
\hline
\end{tabular}

b Correlation of the GDSd with the memory tests

\begin{tabular}{lcll}
\hline & MMSE & IT & DT \\
\hline GDSd & & & \\
$\quad$ Pearson correlation & $-0.324^{* *}$ & $0.415^{* *}$ & $-0.730^{* *}$ \\
Sig. (bilateral) & 0.000 & 0.000 & 0.000 \\
Number & 269 & 269 & 269 \\
\hline
\end{tabular}

IT = Immediate texts without questions; DT = deferred texts without questions. $^{* *} \mathrm{p}=0.01$ (bilateral).

Table 6. Correlations of memory tests with the dimensions and sums of the SF-36

\begin{tabular}{|c|c|c|c|c|c|c|c|c|c|c|}
\hline & $\mathrm{PF}$ & $\mathrm{RP}$ & $\mathrm{BP}$ & $\mathrm{GH}$ & VT & SF & $\mathrm{RE}$ & MH & PCS & MCS \\
\hline \multicolumn{11}{|l|}{ MMSE } \\
\hline Pearson correlation & $0.134 *$ & $0.117^{*}$ & 0.106 & 0.063 & $0.129 *$ & 0.091 & $0.165^{* *}$ & $0.198^{* *}$ & $0.176^{* *}$ & 0.066 \\
\hline Sig. (bilateral) & 0.017 & 0.037 & 0.059 & 0.261 & 0.022 & 0.106 & 0.003 & 0.000 & 0.002 & 0.244 \\
\hline \multicolumn{11}{|l|}{ IT } \\
\hline Pearson correlation & -0.043 & -0.015 & -0.064 & -0.027 & -0.052 & 0.021 & 0.014 & $0.110^{*}$ & -0.087 & 0.075 \\
\hline Sig. (bilateral) & 0.449 & 0.794 & 0.254 & 0.626 & 0.352 & 0.703 & 0.801 & 0.049 & 0.123 & 0.181 \\
\hline \multicolumn{11}{|l|}{ DT } \\
\hline Pearson correlation & $0.117^{*}$ & 0.025 & 0.063 & 0.081 & $0.123^{*}$ & 0.081 & 0.066 & $0.193^{* *}$ & 0.039 & $0.137^{*}$ \\
\hline Sig. (bilateral) & 0.038 & 0.661 & 0.267 & 0.152 & 0.029 & 0.149 & 0.240 & 0.001 & 0.492 & 0.015 \\
\hline Number & 317 & 317 & 317 & 317 & 317 & 317 & 317 & 317 & 317 & 317 \\
\hline
\end{tabular}

of the state of health and QoL $[4,22]$. The general sample of this study conducted in Bizkaia presents a better state of health and perception of their QoL compared to the Spanish population aged more than 60 years [21]. The men as well as the women generally presented better scores than those established as a reference for their gender, and the men showed a 
Garcia Villanueva et al.: Quality of Life in an Adult Population of More than 60 Years of Age without Cognitive Impairment

worse score than the Spanish reference in only one of the dimensions, bodily pain, by reporting more pain.

It was observed that the women presented a worse perception of their QoL than the men, as is also seen in other studies [5], while only in one of the dimensions, bodily pain, did the men show worse health than the women.

Despite expecting a strong relation between each type of activity with the related dimensions of the QoL test $[23,24]$, we did not find significant correlations between the QoL perceived by the sampled persons and the activities they carry out. This may be due to the fact that on average the number of activities performed by the participants does not reach 2 per person; therefore, there will be individuals who carry out many activities, which may give them a better perception of their health, but other persons barely carry out any activity at all, and for this reason, the good perception of their state of health cannot be attributed to the performance of activities. It should also be taken into account that the study does not include intensity [25] and frequency with which they carry out the activities [26] as well as the type of exercise they do, for example, if it is aerobic [23], or if they have abandoned any of the activities. The recording of more years would be needed in order to analyse whether the persons that keep being physically [27] and mentally active as they age show a better performance of the activities, better health and therefore also a better QoL $[28,29]$ and do not deteriorate cognitively [30], or whether this might actually accelerate the process of cognitive impairment, as some studies suggest [31].

The perception of the family members that served as informants is well adapted to the cognitive state of the study participants, which agrees with the studies that state that the information provided by the informants may identify early deterioration [32]. There are very few informants who present different results to those of the evaluator; in those cases where they did, it is due to the score the subjects obtained in the memory tests, where they did not state any problem in their daily activities, but their cognitive level had actually commenced to decrease. We believe that having conducted the GDS test of the family members (GDSf) mostly by telephone did not influence the results like in other studies [33], because the evaluator was the same for all cases and contacted the informants after having evaluated the subjects; therefore, he knew the subjects' state of health and combined the information provided by the informants with the objective memory measurements [32].

As for the cognitive state, contrary to other studies that related carrying out activities with an improvement in memory and with cognitive performance [23, 34], we did not find a relation between not presenting any deterioration in the memory tests and the perception that each one has of his/her QoL or the LA they carry out. It would be necessary to compare the data of the sample of different years to analyse the beneficial effects [17].

In summary, the sampled older adults had a good perception of their health; however, it is necessary to analyse what variables influenced their perception since, as has been seen, in this case the cognitive state and the activities performed did not have a great influence. It is also necessary to compare the QoL of these persons and how they evolve over various years, identifying the causes of possible changes.

\section{Acknowledgements}

The authors wish to thank the Association of Retired Persons of Bizkaia and the older adult area of the Bilbao Bizkaia Kutxa (Kutxabank) for their collaboration and permission to evaluate the persons in their centres. 


\section{References}

1 Carod-Artal FJ: Escalas específicas para la evaluación de la calidad de vida en el ictus. Rev Neurol 2004;39: 1052-1062.

-2 García Ordóñez MA, Mansilla Francisco JJ, Nieto Aragón E, Cereto MR, Salas Samper F, Vallejo Díaz M, et al: Calidad de vida relacionada con la salud de pacientes infectados por VIH medida por el Cuestionario de Salud SF-36. An Med Interna 2001;18:74-79.

-3 Ruiz de Velasco I, Quintana JM, Padierna JA, Aróstegui I, Bernald A, Pérez-Izquierdo J, et al: Validez del cuestionario de calidad de vida SF-36 como indicador de resultados de procedimientos médicos y quirúrgicos. Rev Calid Asist 2002;17:206-212.

4 Lobo A, Santos MP, Carvalho J: The institutionalized elderly: quality of life and functionality. Rev Esp Geriatr Gerontol 2007;42:22-26.

5 Azpiazu Garrido M, Cruz Jentoft A, Villagrasa Ferrer JR, Abanades Herranz JC, García Marín N, Álvarez de Mon Rego C: Calidad de vida en mayores de 65 años no institucionalizados de dos áreas sanitarias de Madrid. Aten Primaria 2003;31:285-294.

6 Blesa R, Pujol M, Aguilar M, Santacruz P, Bertrán-Serra I, Hernández G, et al: Clinical validity of the 'minimental state' for Spanish speaking communities. Neuropsychologia 2001;39:1150-1157.

7 Barnes D, Yaffe K: The projected effect of risk factor reduction on Alzheimer's disease prevalence. Lancet Neurol 2011;10:819-828.

8 Martí-Vilalta JL, Belvís R, Martí-Fábregas J: Factores de riesgo y prevención; in Martí-Vilalta JL (ed): Enfermedades vasculares cerebrales. Barcelona, Prous Science, 2004, pp 43-58.

9 López Pérez-Díaz A, Jiménez-Jaimez J: La hipertensión arterial como factor de riesgo para el deterioro cognitivo en la vejez: estudio de revisión. Psicogeriatría 2011;3:19-28.

$>10$ Molander L, Gustafson Y, Lövheim H: Longitudinal associations between blood pressure and dementia in the very old. Dement Geriatr Cogn Disord 2010;30:269-276.

-11 Kloppenborg RP, Van Den Berg E, Kappelle LJ, Biessels GJ: Diabetes and other vascular risk factors for dementia: which factor matters most? A systematic review. Eur J Pharmacol 2008;585:97-108.

12 Li J, Wang YJ, Zhang M, Xu ZQ, Gao CY, Fang CQ, et al: Vascular risk factors promote conversion from mild cognitive impairment to Alzheimer disease. Neurology 2011;76:1485-1491.

13 Anstey KJ, Von Sanden C, Salim A, O’Kearney R: Smoking as a risk factor for dementia and cognitive decline: a meta-analysis of prospective studies. Am J Epidemiol 2007;166:367-378.

14 Escribano Aparicio MV, Pérez-Dively M, García García FJ, Pérez Martín A, Romero L, Ferrer G: Validación del MMSE de Folstein en una población española de bajo nivel educativo. Rev Esp Geriatr Gerontol 1999;34:319326.

15 Peña Casanova J: Revised Barcelona Test: Subtest 33, Memoria de Textos 82. Barcelona, Masson, 2005.

16 Alonso J, Prieto L, Antó JM: La versión española del SF-36 Health Survey (Cuestionario de Salud SF-36): un instrumento para la medida de los resultados clínicos. Med Clín (Barc) 1995;104:771-776.

17 Wang H, Xu W, Pei J: Leisure activities, cognition and dementia. Biochim Biophys Acta 2012;1822:482-491.

18 Reisberg D, Ferris SH, De León MJ, Crook T: The Global Deterioration Scale for assessment of primary degenerative dementia. Am J Psychiatry 1982;139:1136-1139.

19 Alonso J: Manual de puntuación de la versión española del Cuestionario SF-36. Barcelona, Institut Municipal d'Investigació Mèdica, 2000.

20 Vilagut G, Ferrer M, Rajmil L, Rebollo P, Permanyer-Miraldad G, Quintana JM, et al; por los investigadores de la Red-IRYSS: El Cuestionario de Salud SF-36 español: una década de experiencia y nuevos desarrollos. Gac Sanit 2005;19:135-150.

-21 López-García E, Banegas JR, Graciani Pérez-Regadera A, Gutierez-Fisac JL, Alonso J, Rodriguez-Artalejo F: Valores de referencia de la versión española del Cuestionario de Salud SF-36 en población adulta de más de 60 años. Med Clin (Barc) 2003;120:568-573.

-22 Azpiazu Garrido M, Cruz Jentoft A, Villagrasa Ferrer JR, Abanades Herranz JC, García Marín N, Alvear Valero de Bernabé F: Factores asociados a mal estado de salud percibido o a mala calidad de vida en personas mayores de 65 años. Rev Esp Salud Pública 2002;76:683-699.

23 Baker LD, Frank LL, Foster-Schubert K, Green PS, Wilkinson CW, McTiernan A, et al: Effects of aerobic exercise on mild cognitive impairment: a controlled trial. Arch Neurol 2010;67:71-79.

24 Mora M, Villalobos D, Araya G, Ozols A: Perspectiva subjetiva de la calidad de vida del adulto mayor, diferencias ligadas al género y a la práctica de la actividad físico recreativa. Rev MHSalud 2004;1:1.

25 Middleton LE, Manini TM, Simonsick EM, Harris TB, Barnes DE, Tylavsky F, et al: Activity energy expenditure and incident cognitive impairment in older adults. Arch Intern Med 2011;171:14.

-26 Moore SC, Patel AV, Matthews CE, Berrington de Gonzalez A, Park Y, Katki HA, et al: Leisure time physical activity of moderate to vigorous intensity and mortality: a large pooled cohort analysis. PLoS Med 2012; 9:e1001335.

27 Verdelho A, Madureira S, Ferro JM, Baezner H, Blahak C, Poggesi A, et al; LADIS study: Physical activity prevents progression for cognitive impairment and vascular dementia: results from the LADIS (Leukoaraiosis and Disability) study. Stroke 2012;43:3331-3335.

28 De la Barrera ML, Donolo D, Rinaudo MC: Riesgo de demencia y niveles de educación: cuando aprender es más saludable de lo que pensamos. An Psicol 2010;26:34-40. 
29 Li S, Jin M, Zhang D, Yang T, Koeglsperger T, Fu H, et al: Environmental novelty activates $\beta_{2}$-adrenergic signaling to prevent the impairment of hippocampal LTP by A $\beta$ oligomers. Neuron 2013;77:929-941.

-30 Middleton L, Barnes DE, Lui LY, Yaffe K: Physical activity over the life course and its association with cognitive performance and impairment in old age. J Am Geriatr Soc 2010;58:1322-1326.

-31 Wilson RS, Barnes LL, Aggarwal NT, Boyle PA, Hebert LE, Mendes de Leon CF, et al: Cognitive activity and the cognitive morbidity of Alzheimer disease. Neurology 2010;75:990-996.

32 Rabin LA, Wang C, Katz MJ, Derby CA, Busche H, Lipton RB: Predicting Alzheimer's disease: neuropsychological tests, self-reports, and informant reports of cognitive difficulties. JAm Geriatr Soc 2012;60:1128-1134.

-33 González-Guerrero JL, Herrero JL, Alonso MT, García-Gutiérrez, Arana A: Escala Global de Deterioro. ¿Es fiable su realización mediante entrevista telefónica? Rev Esp Geriatr Gerontol 2003;38:198-202.

-34 Erickson K, Voss MV, Prakash RS, Basak C, Szabo A, Chaddock L, et al: Exercise training increases size of hippocampus and improves memory. Proc Natl Acad Sci USA 2011;108:3017-3022. 